\title{
The Spillover Effects of U.S. Monetary Policy on Global Economy
}

\author{
Siyuan Geng ${ }^{1 *}$, Chenxiao Lu², Qianyi Zhang ${ }^{3}$
}

\author{
${ }^{1}$ Keio University, Tokyo 1088345, Japan \\ ${ }^{2}$ College of Civil Engineering and Architecture, Zhejiang University, Hangzhou, Zhejiang 310058, China \\ ${ }^{3}$ College of Foreign Language and Literature, Fudan University, Shanghai,200433, China \\ *Corresponding author.Email: gengsiyuan0329@gmail.com
}

\begin{abstract}
This paper uses VAR model and select total assets of Federal Reserve, CPI, total manufacturing/industrial production, REER (real broad effective exchange rate adjusted by relative consumer prices), net exports and 3-month interbank rate as indicators to measure the impact of the US monetary policy on China, Japan, EU Area and Canada. There are several key findings. Firstly, US monetary policy shock has spillover effects on the national production, consuming price and central bank action. Secondly, the change of the value of US dollar does not have significant effect on exchange rate for China, EU Area and Japan due to the adoption of flexible exchange rate, while there is significant change in Canada. Thirdly, the monetary policy shock from US is not transmitted to national trade. Finally, the decline of real effective exchange rate in the short-run shows the increasing external competitiveness.
\end{abstract}

Keywords: U.S Monetary Policy, Spillover Effects, VAR model

\section{INTRODUCTION}

Since the mid-1990s, the loose monetary environment has become the basic feature of American monetary policy. The continuous easing of money supply has injected a lot of liquidity into the international financial market. Moreover, with economic impacts of COVID-19, the expected monetary policy will continue for a long time.

As a superpower, the United States has a significant impact on the global economy. Both loose and tight monetary policies made by the Federal Reserve will inevitably affect the monetary environment of other economies through direct or indirect channels. What kind of external impact effect will be produced by the continuous easing monetary policy of the United States has become an important topic of macroeconomic research. For different countries, the impacts are obviously different. However, the discussions on the spillover effects of US monetary policy focused on macroeconomic variables are relatively few. Therefore, we hope to study the spillover effects of US monetary policy on different countries' macroeconomic variables in this study.

Taking China, Japan, Canada and Europe as examples, we choose total assets, CPI, PMI, total manufacturing growth rate previous period (change rate), real broad effective exchange rate adjusted by relative consumer prices (change rate), net exports (change rate) and 3 month interbank rate (change rate) as the embodiment of influence. This paper analyzes the impacts of U.S. monetary policy on the real economy of various countries, and the spillover effects of U.S. monetary policy are different for different countries.

Through literature researching, we studied the effects of total assets, CPI, PMI, total manufacturing growth, real broad effective exchange rate, net exports and interest rate on US monetary policy, and found the relationship between trade, prices, inflation and U.S. monetary policy, which provides a clear logical thinking for the following research. Through quantitative analysis, we found the following four findings. First, the US monetary-policy shock has spillover effects on national productivity, consumer prices, and central-bank action. Second, because of the use of flexible exchange rates, the value of the dollar has no significant impact on China, the EU region, and Japan, while that of Canada has changed significantly. Third, the US monetary-policy shock does not affect international trade. Finally, the spillover effects of US monetary policy may have a long-lasting influence on some economies. 


\section{LITERATURE REVIEW}

Regarding the spillover effects of the US monetary policy on the macroeconomics of other countries, the current studies mainly focus on output, price levels, exchange rates, international trade, and policy responses.

US monetary policy clearly has an impact on other countries' output. However, due to the different samples and time duration used, results from empirical studies have been inconsistent in the direction and extent of the spillover effect. Dedola et al. and Degasperi et al. studied 36 and 30 foreign economies respectively, and concluded that output and industrial production in both developed and emerging economies would decline after the tight US monetary policy[1,2]. Some researches, however, revealed the diverse responses of output in OECD countries[3], or even the different responses of output in the same country to conventional and unconventional expansionary US monetary policy[4]. Yet Willems argued that US monetary policy had no significant impact on the output of dollarized countries[5].

A similar controversy exists in the studies of price level. Dedola et al. and Degasperi et al. pointed out that the tightening of US monetary policy led to a decline in the price level of most advanced and emerging economies[1,2]. Dahlhaus et al. and Dées and Galesi confirmed through empirical researches that the expansionary US monetary policy caused inflation in advanced economies[6,7]. However, Maćkowiak and Neri and Nobili pointed out respectively that the contraction of US monetary policy would cause price rising in emerging markets and the euro zone[8,9].

The research conclusions on exchange rate response are relatively consistent. Empirical studies showed that the contraction of US monetary policy led to the devaluation of other countries' currencies against the US dollar[1,2,8]. Feldkircher and Huber pointed out that the tightening impact of US monetary policy resulted in the decline of the REER of Latin American countries[10]. Chen et al. pointed out that the different exchange rate responses in emerging markets explained the differences in output and inflation responses among economies [11].

There are relatively few studies on the impact of US monetary policy on other countries' trade. In theory, tightening monetary policy in the United States will lead to the appreciation of the US dollar, thus improving the net exports of other countries. Dedola et al. argued that the tightening of US monetary policy had improved trade balance in most countries[1]. The empirical study of Degasperi et al. showed that the tightening of US monetary policy led to the decline of trade volume and export import ratio in the euro area, but the impact on export import ratio of emerging markets was not significant[2].
There are two views on the literature of other countries dealing with the shock of the US monetary policy. One view is that different countries will make different monetary policies to deal with the quantitative easing of the United States. Another is that emerging economies have virtually the same monetary policies in response to quantitative easing. Chen, et al. pointed out that transnational implications might depend on policy responses to US policy actions[11]. For example, China tightened monetary and credit conditions in response to a decline in US corporate interest rates, which often partly offset their expansionary impact on output growth. In Brazil, credit expansion was enormous. While Anaya et al. thought emerging economies would respond by lowering policy interest rates in response to US shocks, regardless of their exchange-rate regime[12].

\section{DATA AND EMPIRICAL METHODOLOGY}

\subsection{Data}

Previous studies have shown that the change of monetary policy in the United States had a significant impact on other countries' macroeconomic variables. In order to study the spillover effect of US monetary policy more systematically in the context of globalization, we select the euro area, China, Japan and Canada as the research samples. The euro zone is relatively independent of the global economy. Canada, on the other hand, has close ties with the United States in terms of region and economy. There is a growing competitive relationship between China and the United States. Japan's economic status is relatively delicate, because, as an Asian country, it closely connected with the United States. In total, our data contains over 3,900 data-points covering five countries or area from 2005 January to 2021 March, including the US, China, Japan, EU Area (19 countries) as an aggregate, Canada and global economic indicators. And all of the variables are monthly. Our data are collected from national statistical office, international organizations (BIS, OECD) and central banks.

Due to the long term zero lower bond rate, the interest in the US is approaching zero in the recent decade. In order to identify the US unconventional monetary policy, we used total asset in the balance sheet of Federal Reserve. At national level, we collected total manufacturing production/total industrial production excluding construction (MN), CPI, real broad effective exchange rate (REER), value of net export (NEX) and 3month interbank rate (IR) as the indicators to represent the macroeconomy and country's monetary policy rate. 


\subsubsection{Estimation of total industrial production excluding construction for China}

The data of total industrial production excluding construction for China is missing in January of each year, so it is necessary for us to fill in the missing part. Herwadkar et al. analyzed the relationship between PMI and industrial production, using ARDL model[13]. And they found out that PMI is a good indicator of industrial activity in the short run, based on the evidence from India. In this paper, we simply used PMI and total industrial production excluding construction data to construct the ARDL model to find the relationship and to make the prediction of the missing part of total industrial production. The long term relationship could be represented by the equation below:

$$
\begin{gathered}
M N_{-} C N_{t}=a_{0}+\sum_{\substack{i=0 \\
\\
\\
+\varepsilon_{t}}}^{m} b_{i} M N_{-} C N_{t-i}+\sum_{j=1}^{n} c_{j} P M I_{-} C N_{t-j} \\
\end{gathered}
$$

We used data collected from National Bureau of Statistic of China, the estimation sample is from June of 2015 to December of 2020 . The result of estimation is as followings:

Table 1. Estimation Result

\begin{tabular}{|c|c|c|c|c|}
\hline Variable & $\begin{array}{l}\text { Coefficie } \\
\text { nt }\end{array}$ & $\begin{array}{l}\text { Std. } \\
\text { Error }\end{array}$ & t-Statistic & Prob.* \\
\hline MN_CN(-1) & 0.71331 & 0.075537 & 9.443191 & 0 \\
\hline MN_CN(-2) & $\begin{array}{l}- \\
0.178211 \\
\end{array}$ & 0.084979 & $\begin{array}{l}- \\
2.097106\end{array}$ & 0.0375 \\
\hline MN_CN(-3) & 0.204197 & 0.062233 & 3.281173 & 0.0013 \\
\hline MN_CN(-4) & 0.076008 & 0.052901 & 1.436802 & 0.1527 \\
\hline PMI_CN & 0.733968 & 0.055531 & 13.21738 & 0 \\
\hline PMI_CN(-1) & $\begin{array}{l}- \\
0.489274 \\
\end{array}$ & 0.086638 & $\begin{array}{l}- \\
5.647315\end{array}$ & 0 \\
\hline PMI_CN(-2) & 0.204477 & 0.075924 & 2.693162 & 0.0078 \\
\hline C & $\begin{array}{l}- \\
2.883775 \\
\end{array}$ & 2.868236 & $\begin{array}{l}- \\
1.005417 \\
\end{array}$ & 0.3162 \\
\hline R-squared & 0.912862 & \multicolumn{2}{|c|}{$\begin{array}{l}\begin{array}{l}\text { Adjusted } \\
\text { R- } \\
\text { squared }\end{array} \\
\end{array}$} & 0.909142 \\
\hline F-statistic & 245.4382 & \multicolumn{2}{|c|}{ Prob(F-statistic) } & 0.000000 \\
\hline
\end{tabular}

As shown in Table 1, we know that the estimation is significant at $1 \%$ level and the $\mathrm{R}$-squared is over 0.9 , so we estimate the industrial production for China using the equation derived above.

\subsection{VAR and Spillover Effect Analysis}

\subsubsection{VAR model}

When studying the dynamic effects of changes in one variable on other variables, traditional linear regression models or simultaneous equation models cannot sharply capture the dynamic mechanism of such effects. In order to deal with the analysis and prediction of multiple economic indicators, Sims proposed a VAR model, which uses all variables as a system to predict the impact of shocks on the system, so that the predictions are mutually consistent[14]. In this paper, we used VAR model that include 1 lag of the endogenous variables to capture the economic dynamics in country level with the monthly data. Meanwhile, in estimating the VAR model, we used Cholesky identification scheme that assumed the order of the variables in the model should be total assets of Federal Reserve, CPI, total manufacturing/industrial production, REER and net exports and 3-month interbank rate.

$$
Y_{t}=\Phi_{0}+\Phi_{1} Y_{t-1}+\varepsilon_{t}, \quad \varepsilon_{t} \sim W . N .(\Sigma)
$$

In order to acquire the stationarity of time series data, we take the change rate of indicators we collected as the endogenous variables.

\subsubsection{The U.S. monetary policy effect}

As shown in Figure 1, in the wake of a tightening of the US monetary policy stance, the appreciation of US dollar is visible in the response of exchange rate for Canada. The real effective exchange rate decreases in the first 5 months, indicating the depreciation of the national currency. While there is no significant change in Japan, Euro Area and China, indicating that Japan, Euro Area and China do not have flexible exchange rates to insulate the economy from US policy shock, which shows the leadership role of the US.

But at the same time, the appreciation of national currency does not seem to help the trade since there isn't any profound response on the trade for the four countries, especially in Canada. This could be explained as the offset of the increased domestic spending, which means that although the foreign output decreases due to the appreciation of US dollar and thus import of US goods switches out and shifts to domestic goods. However, at the same time, the decreasing of domestic spending due to the recession will reduce the demand for domestic goods. These two effects offset each other in trade channel and eliminate the US monetary policy shock on trade.

What's more, there is a relatively persistent decline in CPI, accompanied with sharp decline in industrial production. This means that the tightening US monetary policy leads to a recession in economies we estimated in this paper. And as the response to the recession, domestic production decreases and the deflation is observed as well. As to the effects of central bank actions, China's action appears to be more significant than other economies. But, overall, central banks for four countries all take the loosening monetary policy in order to eliminate the effect of US policy shock. Something needs to be noticed is that 
in China, 9-10 months after the shock from the US, industrial production and interbank rate both have a small rebound which lasts for a long time. This shows that the
US tightening monetary policy may have a positive effect on China's economy in the long run.
CPI

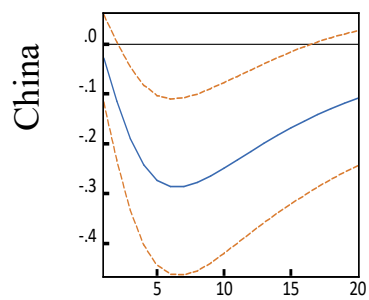

CPI

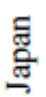

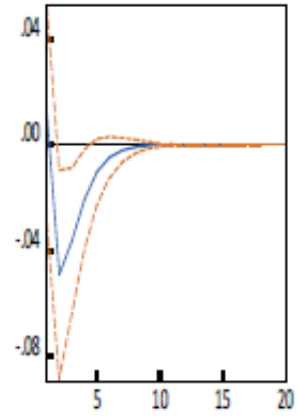

(P)

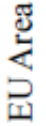
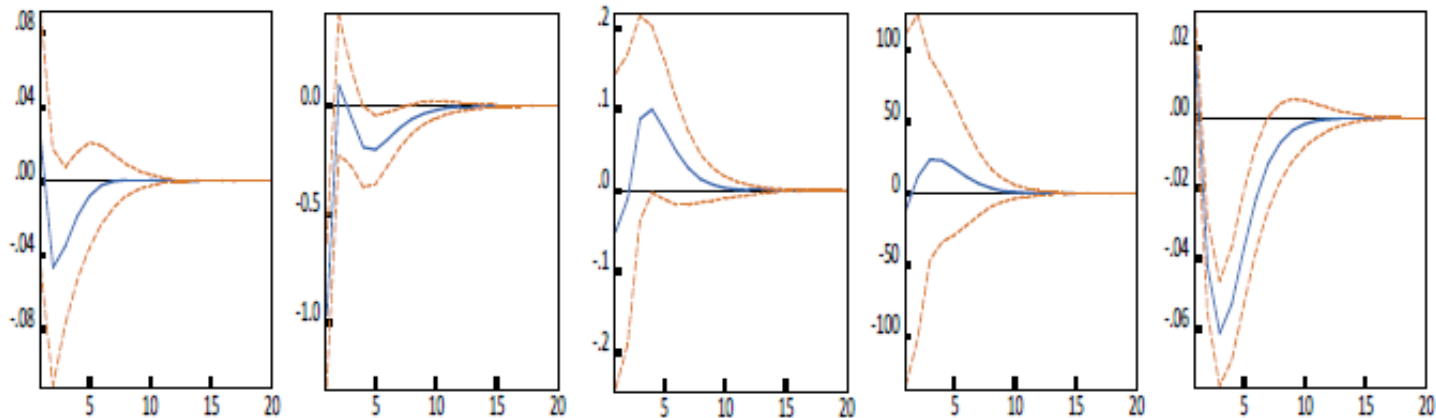

CPI
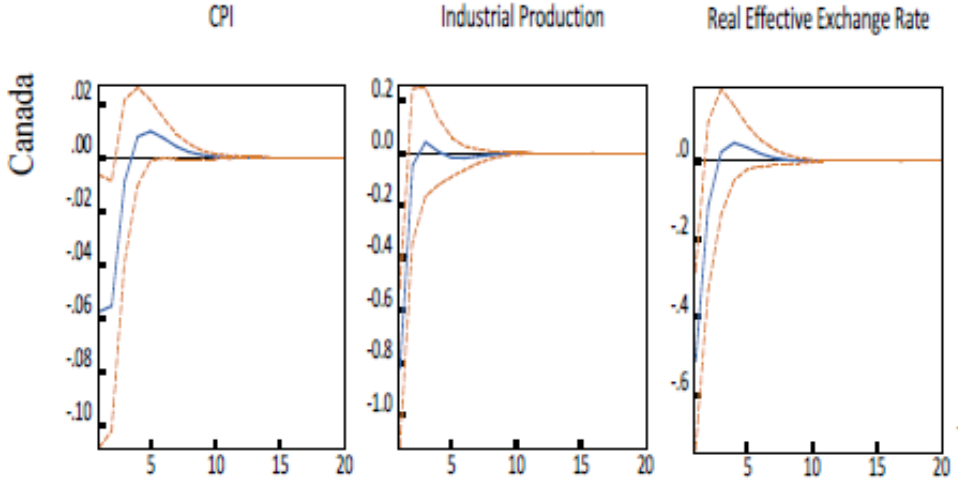

Net Export
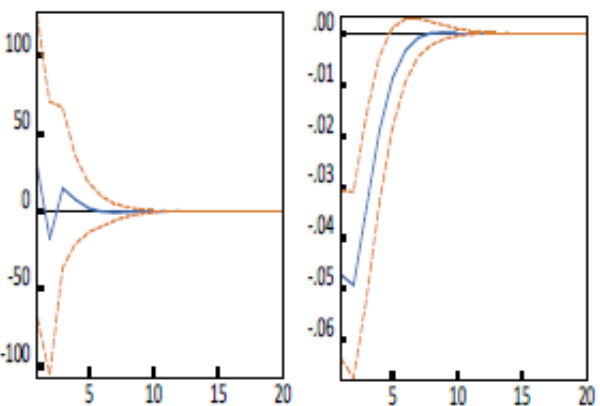

Notes: Median impulse response functions. Blue line - median response of each country level indicators to a US monetary policy shock. Orange line areas $-95 \%$ posterior coverage bands.

Figure 1 US policy shock in four countries 


\section{CONCLUSION}

In this paper, we examine the spillover effects of US monetary policy on China, Japan, EU Area and Canada by implementing VAR model and incorporating dataset of macroeconomic indicators at monthly frequency. We also construct the estimation equation of China's industrial production and PMI using ARDL model. We derive several findings. Firstly, US monetary policy shock has spillover effects on the national production, consuming price and central bank action. Secondly, the change of the value of US dollar does not have significant effect on exchange rate for China, EU Area and Japan due to the adoption of flexible exchange rate, while there is significant change in Canada. Thirdly, the monetary policy shock from US is not transmitted to international trade, probably because of the offset of reduced domestic spending and shift of imports of US goods to domestic expenditure. Fourthly, the spillover effects of US monetary policy may have some permanent influences on some economies. Finally, the decline of real effective exchange rate in the short-run shows the increasing external competitiveness.

\section{REFERENCES}

[1] Dedola, L., Rivolta, G., Stracca, L. (2017). If the Fed sneezes, who catches a cold?. Journal of International Economics, 61: 101-115

[2] Degasperi, R., Hong, S.S., Ricco, G. (2020). The global transmission of u.s. monetary policy. CEPR Discussion Papers.

[3] Kazi, I.A., Wagan, H., Akbar, F. (2013). The changing international transmission of U.S. monetary policy shocks: Is there evidence of contagion effect on OECD countries. Economic Modelling, 30: 90-116.

[4] Kabundi, A., Loate, T., Viegi, N. (2020). Spillovers of the Conventional and Unconventional Monetary Policy from the US to South Africa. South African Journal of Economics, 88: 435-471.

[5] Willems, T. (2013). Analyzing the effects of US monetary policy shocks in dollarized countries. European Economic Review, 61: 101-115.

[6] Dahlhaus, T., Hess, K., Reza, A. (2018). International Transmission Channels of U.S. Quantitative Easing: Evidence from Canada. Journal of Money, Credit and Banking, 50:. 545-563.

[7] Dées, S., Galesi, A. (2021). The Global Financial Cycle and US monetary policy in an interconnected world. Journal of International Money and Finance, 115

[8] Maćkowiak, B. (2007). External shocks, U.S. monetary policy and macroeconomic fluctuations in emerging markets. Journal of Monetary Economics, 54: 2512-2520.

[9] Neri, S., Nobili, A. (2010). The Transmission of US Monetary Policy to the Euro Area. International Finance, 13: 55-78.

[10] Feldkircher, M., Huber, F. (2016). The international transmission of US shocks-Evidence from Bayesian global vector autoregressions. European Economic Review, 81: 167-188.

[11] Chen, Q., Filardo, A., He, D., Zhu, F. (2016). Financial crisis, US unconventional monetary policy and international spillovers. Journal of International Money and Finance, 67: 62-81.

[12] Anaya, P., Hachula, M., Offermanns, C.J. (2017). Spillovers of U.S. unconventional monetary policy to emerging markets: The role of capital flows. Journal of International Money and Finance, 73: 275-295.

[13] Herwadkar, S.S., Ghosh, S. (2020): Is PMI a good leading indicator of industrial production?: Evidence from India. MPRA Paper.

[14] Sims, C. A. (1980) Macroeconomics and Reality. Econometrica, 48:1-48 